\title{
Temporal trend and sources of speciated atmospheric mercury at Waliguan GAW station, Northwestern China
}

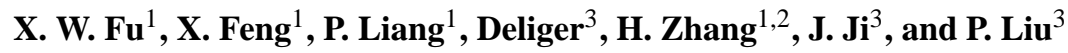 \\ ${ }^{1}$ State Key Laboratory of Environmental Geochemistry, Institute of Geochemistry, Chinese Academy of Sciences, \\ Guiyang 550002, China \\ ${ }^{2}$ Graduate University of the Chinese Academy of Sciences, Beijing 100049, China \\ ${ }^{3}$ China Global Atmosphere Watch Baseline Observatory, Qinghai Meteorological Bureau, Xining, 810001, China \\ Correspondence to: X. Feng (fengxinbin@vip.skleg.cn)
}

Received: 20 September 2011 - Published in Atmos. Chem. Phys. Discuss.: 8 November 2011

Revised: 31 January 2012 - Accepted: 8 February 2012 - Published: 20 February 2012

\begin{abstract}
Measurements of speciated atmospheric mercury were conducted at a remote mountain-top station (Waliguan (WLG) Baseline Observatory) at the edge of northeastern part of the Qinghai-Xizang Plateau, Western China. Mean concentrations of total gaseous mercury (TGM), particulate bound mercury (PBM), and gaseous oxidized mercury (GOM) during the whole sampling campaign were $1.98 \pm$ $0.98 \mathrm{ng} \mathrm{m}^{-3}, 19.4 \pm 18.1 \mathrm{pg} \mathrm{m}^{-3}$, and $7.4 \pm 4.8 \mathrm{pg} \mathrm{m}^{-3}$, respectively. Levels of speciated $\mathrm{Hg}$ at WLG were slightly higher than those reported from remote areas of North America and Europe. Both regional sources and long-rang transport played important roles in the distribution of atmospheric TGM and PBM at WLG, whereas GOM showed major links to the regional sources, likely as well as the in-situ productions via photochemical processes. Regional sources for speciated $\mathrm{Hg}$ were mostly located to the east of WLG, which is the most industrial and urbanized areas of Qinghai province. Potential source contribution function (PSCF) results showed that eastern Gansu, western Ningxia and Shanxi Province were likely the potential source regions of WLG, with good accordance with locations of urban areas and industrial centers. Moreover, we found that Northern India may be a significant source region for WLG during the sampling campaign, and this is the first published evidence suggesting long-range transport of atmospheric $\mathrm{Hg}$ from India to the Northeastern Tibetan Plateau. Seasonal and diurnal variations of TGM were in contrast to most of the previous studies in China, with relatively higher levels in warm seasons and night, respectively. The temporal trend of TGM also highlighted the impact of long-range transport on the distribution of TGM in ambient air at WLG.
\end{abstract}

\section{Introduction}

Mercury $(\mathrm{Hg})$ is a highly toxic and persistent pollutant of global environment concern. There are three major operationally-defined forms of $\mathrm{Hg}$ in the atmosphere: gaseous elemental mercury (GEM), gaseous oxidized mercury $(\mathrm{GOM})$, and particulate bound mercury (PBM), with the sum of GEM and GOM commonly known as total gaseous mercury (TGM) (Gustin and Jaffe, 2010). GEM, the dominant form of total $\mathrm{Hg}$ in the atmosphere $(>90 \%)$, is fairly stable in the lower atmosphere with a residence time of several months to a year, and therefore could be globally dispersed by global atmospheric circulation (Schroeder and Munthe, 1998; Lindberg et al., 2007). Due to the high surface reactivity and water solubility, PBM and GOM have much shorter atmospheric residence times of several hours to weeks and are generally depicted as regional and local pollutants (Schroeder and Munthe, 1998; Sheu and Mason, 2001). Even though present as a small proportion of total $\mathrm{Hg}$ in the atmosphere, GOM and PBM are believed to be crucial in the global biogeochemical cycle of $\mathrm{Hg}$ (Lindberg and Stratton, 1998). This is mainly because GOM and PBM are the dominant pathway for $\mathrm{Hg}$ being scavenged from atmosphere and delivered to remote terrestrial and aquatic ecosystems (Lee et al., 2001; Seigneur et al., 2003).

Both anthropogenic and natural sources release GEM to the atmosphere. According to recently developed models, anthropogenic activities are regarded as the major factors influencing atmospheric $\mathrm{Hg}$ distributions, with anthropogenic sources accounting for about $1 / 3$ of the total emissions (Seigneur et al., 2004; Selin et al., 2007; Pirrone et 
al., 2010). GOM and PBM are emitted primarily from anthropogenic sources. However, many recent studies also found strong evidence of natural productions of GOM and PBM in polar regions (Lu et al., 2001; Lindberg et al., 2002; Cobbett et al., 2007), marine environments (Laurier et al., 2003; Obrist et al., 2010); as well as free troposphere and lower stratosphere (Murphy et al., 2006; Swartzendruber et al., 2006; Faïn et al., 2009). Additionally, many observations conducted at inland sites have also reported consistent elevated levels of GOM during daytime which is probably related to in-situ photochemical production (Poissant et al., 2005; Lynam and Keeler, 2005; Sigler et al., 2009).

Long-term monitoring of atmospheric $\mathrm{Hg}$ at remote sites is an important pathway to assess the regional atmospheric $\mathrm{Hg}$ budget and understand the global cycle of $\mathrm{Hg}$ in the atmosphere. A large number of studies have been made in remote areas in Europe and North America. According to these studies, the average concentrations of GEM, GOM and PBM generally fell in the range of $1.2 \sim 1.9 \mathrm{ng} \mathrm{m}^{-3}, 1.8 \sim 43 \mathrm{pg} \mathrm{m}^{-3}$, $2.2 \sim 26 \mathrm{pg} \mathrm{m}^{-3}$, respectively (Schmolke et al., 1999; Kellerhals et al., 2003; Poissant et al., 2005; Yatavelli et al., 2006; Valente et al., 2007; Choi et al., 2008; Sigler et al., 2009; Engle et al., 2010), with some of the higher levels observed under impacts from regional sources and in-situ photochemical production. A clear temporal trend with decreasing TGM concentrations since 1995 was observed at Mace Head, which corresponded very well with the decreasing anthropogenic emissions in Europe (Ebinghaus et al., 2011). Observations of atmospheric $\mathrm{Hg}$ in remote areas of South Hemisphere are limited. The annual mean TGM concentrations at Cape Point in South Africa ranged from 0.87 to $1.4 \mathrm{ng} \mathrm{m}^{-3}$, with relatively lower levels observed in recent years (Slemr et al., 2011).

Asia is the largest atmospheric $\mathrm{Hg}$ source region over the world, and constitutes more than half of total anthropogenic emissions worldwide (Pirrone et al., 2010; Pacyna et al., 2010). However, atmospheric $\mathrm{Hg}$ in this area is poorly studied. Previous studies conducted in remote areas of

Southern, Southwestern, and Northeastern China revealed highly elevated atmospheric TGM concentrations ranging from 2.8 3.98 $\mathrm{ng} \mathrm{m}^{-3}$ (Fu et al., 2008a, b, 2010a; Wan et al., 2009), and preliminary studies of TGM in marine boundary layer also showed elevated TGM levels (Fu et al., 2010b; $\mathrm{Ci}$ et al., 2011). Also, a highly elevated TGM concentration up to $4.61 \mathrm{ng} \mathrm{m}^{-3}$ was observed from a Global Atmospheric Watch (GAW) station in the An-Myun Island, Korea (Nguyen et al., 2007). These studies indicated that Eastern Asia is seriously polluted with respect to atmospheric $\mathrm{Hg}$.

The Qinghai-Tibetan Plateau, with an average altitude of over $4000 \mathrm{~m}$ a.s.l., is an ideal platform for assessing atmospheric Hg budget in Asia. The Plateau itself has lower population density and sparse distributions of industrial activities. The two largest source regions in the world, Eastern China and India, are located to the east and southwest of the Plateau (Pirrone et al., 2010; Pacyna et al., 2010). In the present study, we conducted one year continuous measurements of TGM at the Mount Waliguan Baseline Observatory at the edge of northeastern part of the Qinghai-Xizang (Tibet) Plateau. Also, we measured PBM and GOM concentrations in three selected seasons. The data sets presented here are crucial for the global mercury observation network and global mercury modeling studies. In addition, it is also important to study the regional atmospheric $\mathrm{Hg}$ budgets of Asia and long-range transport of $\mathrm{Hg}$ to Qinghai-Tibetan Plateau.

\section{Experimental}

\subsection{Site description}

Monitoring of speciated atmospheric $\mathrm{Hg}$ was carried out at the Waliguan (WLG) Baseline Observatory $\left(100^{\circ} 53^{\prime} 52.7^{\circ} \mathrm{E}\right.$, $36^{\circ} 17^{\prime} 12^{\circ} \mathrm{N}, 3816 \mathrm{ma}$ a.s.l.), which is one of the World Meteorological Organization's (WMO) Global Atmospheric Watch (GAW) Baseline Stations. The observatory is situated at the summit of Mt. Waliguan at the edge of northeastern part of the Qinghai-Xizang (Tibet) Plateau (Fig. 1), which is an isolated mountain peak with an elevation of about $600 \mathrm{~m}$ above the surrounding landmass.

WLG is relatively isolated from industrial point sources and populated regions. The surrounding areas of WLG are naturally preserved arid/semi-arid lands and scattered grasslands and there is no local $\mathrm{Hg}$ source around the station. Most of the Chinese $\mathrm{Hg}$ source regions are situated to the east of WLG (Wu et al., 2006). Xining and Lanzhou, which are the two largest industrial regions and populated centers in the northwest of China, are located about 90 and $260 \mathrm{~km}$ to the northeast and east of WLG. There are no large point sources to the west of the WLG, and the population density in this area is generally lower than 10 people per $\mathrm{km}^{2}$.

Wind system at WLG is controlled by Qinghai-Tibet Plateau monsoon, which brings seasonal variations in wind directions with southwestern wind and eastern wind as the predominant wind directions in cold and warm seasons, respectively. At the same time, WLG is also affected by the mountain-valley breezes. During the daytime, the air mass in the lower altitude area of Mt. Waliguan is heated because of increasing solar radiation, resulting in an upslope flow that brings air flows from the boundary layer to the sampling site; while at night, air adjacent to mountain peak cools faster than air in the low altitude area, causing a reversal flow (downslope), which enables transport of air masses from the free troposphere to the sampling site. During the study period, annual mean air temperature, relative air humidity, wind speed and precipitation were $-1.7^{\circ} \mathrm{C}, 41.6 \%, 4.6 \mathrm{~m} \mathrm{~s}^{-1}$, and $350 \mathrm{~mm}$, respectively.

\subsection{Measurements of speciated atmospheric $\mathrm{Hg}$}

Real time continuous (every $10 \mathrm{~min}$ ) measurements of TGM were conducted from 22 September 2007 to 


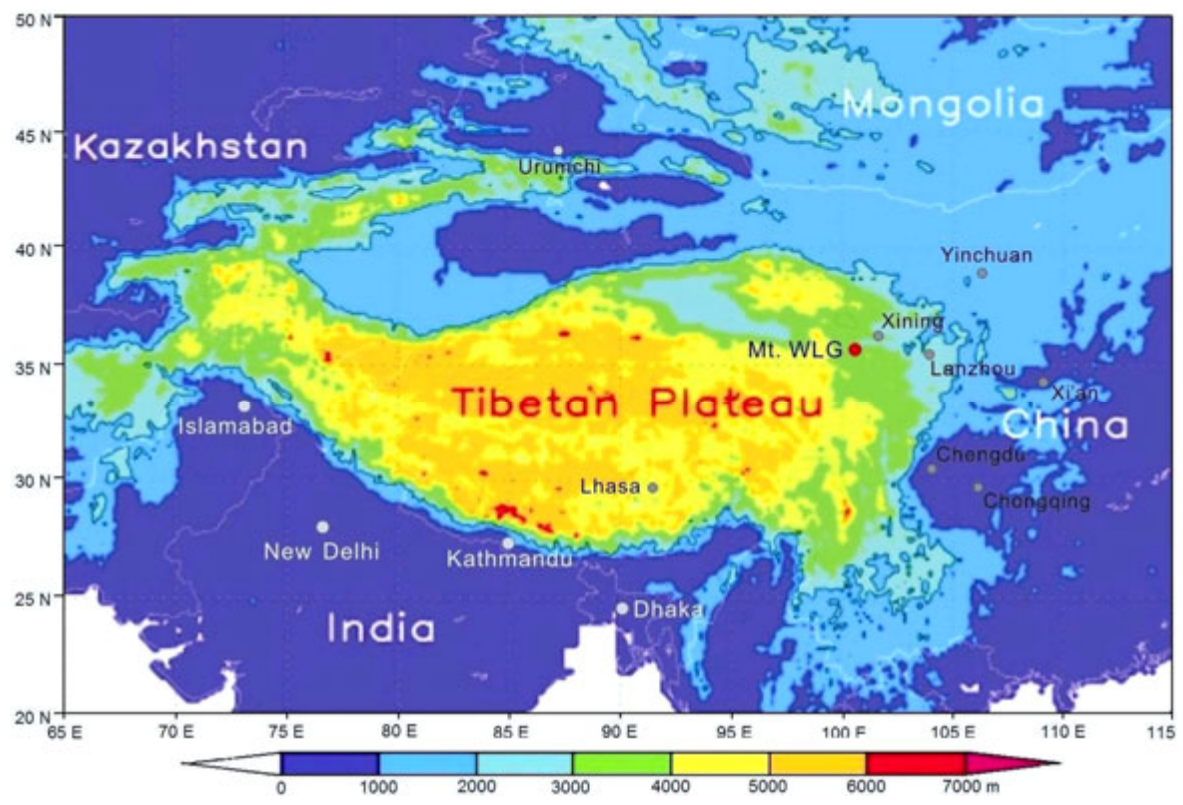

Fig. 1. Map showing the location of Mount Waliguan Observatory Baseline.

21 September 2008 using an automated $\mathrm{Hg}$ vapor analyzer (Tekran 2537A). Its technique is based on the collection of TGM on gold traps, followed by thermal desorption, and detection of $\mathrm{Hg}^{0}$ by cold vapor atomic fluorescence spectrometry $(=253.7 \mathrm{~nm})$. The instrument has two cartridges which trap gaseous $\mathrm{Hg}$ on to gold absorbents. While one cartridge is adsorbing $\mathrm{Hg}$ during sampling period, the other is being desorbed thermally and analyzed subsequently for TGM. The functions of each cartridge are then reversed, allowing continuous sampling of ambient air. The analyzer was set up in a temperature-controlled laboratory $\left(24-26^{\circ} \mathrm{C}\right)$. Fresh ambient air was introduced to the inlet of the analyzer by using a $25 \mathrm{ft}$ heated Teflon tube $\left(50^{\circ} \mathrm{C}\right)$ with its sampling inlet $2.5 \mathrm{~m}$ above the roof. A $47-\mathrm{mm}$ diameter quartz fiber filter at the inlet of the heated Teflon tube and a Teflon filter (pore size $0.2 \mu \mathrm{m}$ ) mounted behind the Tekran 2537A were used to remove particulate matters, which were replaced every two weeks. The analyzer was programmed to measure atmospheric TGM at the time resolution of $10 \mathrm{~min}$ and at a flow rate of $0.751 \mathrm{~min}^{-1}$. The detection limit of TGM in this study was about $0.1 \mathrm{ng} \mathrm{m}^{-3}$. Data quality of the analyzer was controlled via periodic internal recalibration with a $25 \mathrm{~h}$ interval, and the emission rate of internal permeation source was calibrated every 4 months.

Sampling and analysis of atmospheric GOM and PBM were carried out by using the method developed by Landis et al. (2002), which showed details of quartz annual denuder design, pre-clean method, denuder coating, and thermally conditioned method. Quartz annular denuder (URG) was positioned vertically in the temperature-controlled laboratory, and ambient air was introduced to the inlet of denuders by using the $25 \mathrm{ft}$ heated $\left(50^{\circ} \mathrm{C}\right)$ Teflon tube. The inlet of denuder consists of an integrated elutriator/acceleration jet and a glass impactor plate which removes coarse particles $(>2.5 \mu \mathrm{m})$ in ambient air. Air samples were collected for 3.5 or $7.5 \mathrm{~h} \mathrm{du}-$ ration with a volumic flow rate of $10 \mathrm{~L} \mathrm{~min}^{-1}$. It should be pointed out that, due to the extreme environment condition at the station, we were unable to install the sampling system of PBM and GOM outside the building. The use of $25 \mathrm{ft}$ heated Teflon tube might result in some adsorption of PBM and especially GOM to the Teflon tubing and cause artifacts (mainly underestimates) to the final concentrations observed (Landis et al., 2001). However, we speculate that this artifact may not affect to our result significantly due to the several following reasons. Firstly, the sampling air had a very short residence time $(\sim 2 s)$ inside the Teflon tubing, which is shorter than the commercial manifold (Tekran 1104 sample manifold) recently developed for atmospheric Hg studies under extreme environment conditions. Also, the Teflon tubing was kept at a relatively high temperature of $50^{\circ} \mathrm{C}$, which might decrease the adsorption of GOM and PBM to the Teflon tubing.

During sampling, temperature of the denuder was maintained at about $40-50{ }^{\circ} \mathrm{C}$ using a temperature controlled heating sleeve. Fine fraction $(<2.5 \mu \mathrm{m}) \mathrm{PBM}$ in ambient air downstream of the denuder was collected onto a $47 \mathrm{~mm}$ diameter quartz fiber filter housed in a Teflon coated filter holder. Before sampling, the quartz fiber filter was precleaned by heating it at $850{ }^{\circ} \mathrm{C}$ for $30 \mathrm{~min}$. We tried to obtain a low blank for the quartz fiber filters for sampling, however, a relatively high mean background of $4.0 \pm 1.9 \mathrm{pg}$ $(0.8 \sim 8.0 \mathrm{pg}, n=18)$ was observed. We made blank correction for all the PBM concentrations by subtracting the mean blank of quartz filter. All the quartz filters were used for only 
one sampling cycle to prevent from possible deformation and pollutions. In this study, we used two types of sampling durations for GOM and PBM sampling, which were $7.5 \mathrm{~h}$ during 00:00 08:00 and 3.5 h during 08:00 24:00 (local time), respectively. Landis et al. (2002) tested the field collection efficiencies of the denuder and found that the efficiencies were relatively stable ( $92 \% \sim 94 \%)$ for $1 \sim 12 \mathrm{~h}$ sampling durations. For the fine fraction PBM, it was also observed that there is no consistent difference in PBM concentrations of different sampling durations (Malcolm and Keeler, 2007).

Upon completion of the field sampling, the denuder was sealed immediately and the quartz fiber filter was transported into a quartz glass tube (URG) using clean techniques. Denuder and filter were firstly flushed with zero gas for about $10 \mathrm{~min}$. Then the denuders and filters were rapidly heated to $500^{\circ} \mathrm{C}$ and $850^{\circ} \mathrm{C}$ for about $15 \mathrm{~min}$ using a tube furnace (Thermo Scientific), respectively. GOM and PBM trapped onto denuders and quartz fiber filters were thermally decomposed to $\mathrm{Hg}^{0}$ and detected by Tekran 2537A. In order to minimize the effect of other compounds collected by the denuders on the Tekran 2537A gold trap collection efficiencies during thermal desorption, a soda and lime trap was installed in the sampling line of Tekran 2537A and replaced routinely (Landis et al., 2002). Atmospheric PBM and GOM concentrations were calculated by taking the sum of the three heating cycles for each analyte and subtracting 3 times the last zero air value prior to desorption (Landis et al., 2002). Fresh glass impactors and denuders were replaced periodically. Quality assurance and quality control for PBM and GOM were conducted using duplicates and field blanks. The relative mean differences of duplicated PBM and GOM samples $(N=10)$ were $22 \pm 28 \%$ and $19 \pm 22 \%$, respectively. The field blanks of quartz fiber filters and denuders were $4.0 \pm 1.9 \mathrm{pg}(N=18)$ and $1.3 \pm 0.5 \mathrm{pg}(N=7)$, respectively. The detection limits for PBM and GOM in our study were 4.2 and $1.2 \mathrm{pg} \mathrm{m}^{-3}$, respectively, based on 3 times the standard deviation of blanks.

In this study, GOM and PBM measurements were conducted in three individual months, September 2007 (22 to 30 September), January 2008 (13 to 22 January), and July 2008 (5 to 19 July), which represents the three different seasons of autumn, winter, and summer, respectively.

\subsection{Backward trajectories and Potential Source Contribution Function (PSCF) analysis}

In order to identify the possible impacts of long-range transport on the distribution of atmospheric Hg at WLG, threedimensional air mass backward trajectories arriving at WLG at the heights of 500,1000, and $1500 \mathrm{~m}$ above the ground level were calculated using a Geographical Information System based software (Wang et al., 2009) and gridded meteorological data (Global Data Assimilation System, GDAS1) from the U.S. National Oceanic and Atmospheric Administration (NOAA). Horizontal domain of the gridded meteoro- logical data are on a 360 by 181 degree latitude-longitude with a horizontal resolution of $1 \times 1$ degree latitude/longitude and a vertical levels of 23 from $1000 \mathrm{hPa}$ to $20 \mathrm{hPa}$. Since atmospheric $\mathrm{Hg}$ species have quite different atmospheric residence times, backward trajectories with total run times of 120, 48, and 48 hours were calculated for TGM, GOM and PBM, respectively. Backward trajectories used for further TGM sources identification were calculated every $24 \mathrm{~h}$, while they were calculated very $4 \mathrm{~h}$ or $8 \mathrm{~h}$ for PBM and GOM. Hence, we collected 888, 435, and 435 trajectories for TGM, PBM, and GOM, respectively.

The calculated backward trajectories were used to make Potential Source Contribution Function (PSCF) analysis of atmospheric $\mathrm{Hg}$ species at MLG, which has been applied in many previous studies to identify possible source areas for the measured atmospheric pollutants (e.g. Kim et al., 2005; Choi et al., 2008). The PSCF values for the grid cells in the study domain were calculated by counting the trajectory segment endpoints that terminate within each cell. The number of endpoints that fall in the $i j_{t h}$ cell is designated as $N_{i j}$. The number of endpoints for the same cell corresponding to concentrations higher than an arbitrarily set criterion (1.98 $\mathrm{ng} \mathrm{m}^{-3}, 19.4 \mathrm{pg} \mathrm{m}^{-3}$, and $7.4 \mathrm{pg} \mathrm{m}^{-3}$ for TGM, PBM, and GOM, respectively, which are the mean levels during the whole sampling period. We did not observe significant deviations in potential source regions using different arbitrarily set criterions such as the mean concentrations and 75th levels of speciated atmospheric $\mathrm{Hg}$ ) is defined to be $M_{i j}$. The PSCF value for the $i j_{t h}$ cell is then defined as

$\operatorname{PSCF}_{i j}=\frac{M_{i j}}{N_{i j}}$

Since backward trajectories starting at different heights traverse different distances and pathways, multiple height PSCF analysis was performed with starting elevations of 500 , 1000 , and $1500 \mathrm{~m}$ above the ground level. Since each of the endpoint may contain source information of the grid cell, endpoints "grounded" were not excluded in this study. The total endpoints in the geophysical region covered was 94947 for TGM, and 21022 for PBM and GOM, and the geophysical region was divided into 4132 grid cells of $0.5 \times 0.5$ latitude and longitude. To reduce the effect of small values of $N_{i j}$, the PSCF values were multiplied by an arbitrary weight function $W_{i j}$ to better reflect the uncertainty in the values for these cells (Polissar et al., 2001). The weighting function reduced the PSCF values when the total number of the endpoints in a particular cell $\left(\mathrm{N}_{i j}\right)$ was less than about three times the average value $\left(N_{\text {ave }}\right)$ of the end points per each cell:

$$
W_{i j}= \begin{cases}1.0 & N_{i j}>3 N_{\mathrm{ave}} \\ 0.70 & 3 N_{\mathrm{ave}}>N_{i j}>1.5 N_{\mathrm{ave}} \\ 0.40 & 1.5 N_{\mathrm{ave}}>N_{i j}>N_{\mathrm{ave}} \\ 0.20 & M_{\mathrm{ave}}>N_{i j}\end{cases}
$$


Although trajectory and PSCF calculations are powerful tools for atmospheric source identifications and have been widely used in many previous literatures (e.g. Kim et al., 2005; Choi et al., 2008), there are many limitations and uncertainties associated with the trajectory calculation and PSCF analysis. Here, we made a rough estimate of the uncertainties associated with trajectory calculations by performing forward and backward trajectory calculations originated from the source and receptor locations. It is found that horizontal and vertical deviations between the corresponding endpoints of backward trajectories and forward trajectories increased with run time and the mean horizontal and vertical deviations at the 120th hour were about $670 \mathrm{~km}$ and $830 \mathrm{~m}$, respectively, and this approximately yields an uncertainty of $17 \%-24 \%$ for the study domain.

\subsection{Meteorological parameters}

10-min averaged meteorological data measured at $10 \mathrm{~m}$ above the ground, including wind direction, wind speed, air temperature, and air humidity, were obtained from the Waliguan (WLG) Baseline Observatory.

\section{Results and discussion}

\subsection{General characteristics}

Figures 2 and 3 show the time series of TGM, PBM, and GOM concentrations at WLG during the whole sampling campaign. Both TGM and PBM showed significant variations with many high concentration episodes; whereas GOM concentrations exhibited a relatively constant level. Generally, GOM has a very short atmospheric residence time and is regarded as a precursor of nearby sources. The repeatedly observed high TGM and PBM episodes and relatively constant levels of GOM likely indicate a more pronounced impact of long-range transport at the sampling site compared to the local and regional sources.

Mean concentrations of TGM, PBM, and GOM during the whole sampling campaign were $1.98 \pm 0.98 \mathrm{ng} \mathrm{m}^{-3}$ (the geometric mean concentration was used here because the data sets followed a log normal distribution pattern), $19.4 \pm 18.1 \mathrm{pg} \mathrm{m}^{-3}$, and $7.4 \pm 4.8 \mathrm{pg} \mathrm{m}^{-3}$, respectively. Levels of atmospheric $\mathrm{Hg}$ species at WLG were much lower than those observed at Guiyang city, Southwestern China (means: $9.72 \mathrm{ng} \mathrm{m}^{-3}$ (GEM); $368 \mathrm{pg} \mathrm{m}^{-3}$ (PBM); $\left.35.7 \mathrm{pg} \mathrm{m}^{-3}(\mathrm{GOM})\right)$, a polluted city with many large point and domestic Hg sources (Feng et al., 2003, 2004; Fu et al., 2011). In general, atmospheric TGM levels in remote areas are closely related to the regional atmospheric $\mathrm{Hg}$ budget. TGM concentrations at WLG were much lower than the background value $\left(2.80 \pm 1.51 \mathrm{ng} \mathrm{m}^{-3}\right)$ of TGM in Guizohu province, one of the largest $\mathrm{Hg}$ source regions in China $(\mathrm{Fu}$ et al., 2010a), and also lower than the annual mean value of

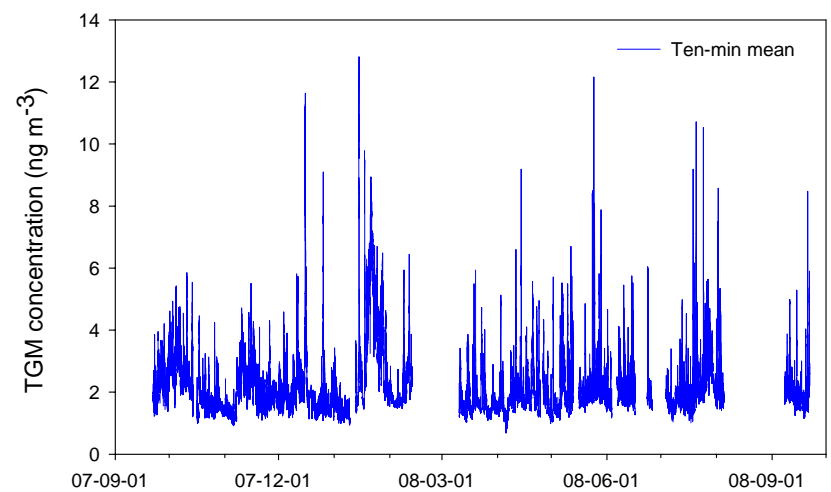

Fig. 2. Time series of the distribution of TGM concentrations in ambient air at Mount Waliguan Observatory Baseline.

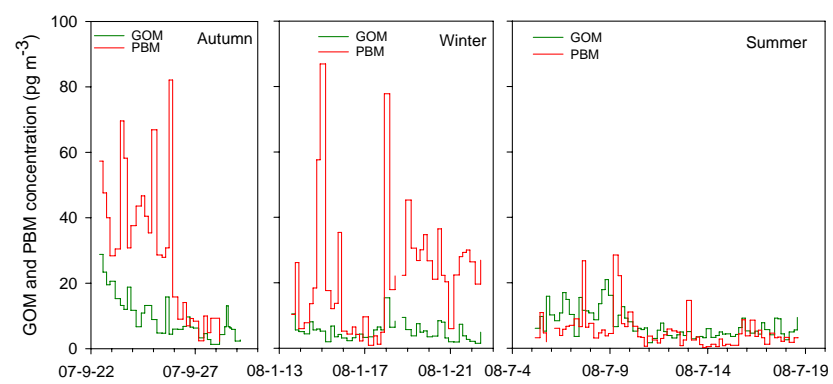

Fig. 3. Time series of PBM and GOM concentrations during the selected sampling campaigns.

$2.59 \pm 1.33 \mathrm{ng} \mathrm{m}^{-3}$ obtained at the edge of southeastern Tibetan Plateau (Shangri-la station, the regional background station in Southwestern China belongs to Chinese Meteorological station, Zhang et al., 2011), but they were relatively higher than the mean value of $1.60 \pm 0.51 \mathrm{ng} \mathrm{m}^{-3}$ observed at Mt. Changbai area, Northeastern China (Fu et al., 2012).

Levels of atmospheric $\mathrm{Hg}$ species at WLG were relatively higher than those observed in remote areas of North America and Europe. For example, ranges of speciated Hg concentrations in remote areas of Middle and Eastern United States were $1.27 \sim 1.62 \mathrm{ng} \mathrm{m}^{-3}$ for GEM $2.2 \sim 9.1 \mathrm{pg} \mathrm{m}^{-3}$ for $\mathrm{PBM}$, and $1.8 \sim 5.2 \mathrm{pg} \mathrm{m}^{-3}$ for GOM, respectively (Choi et al., 2008; Sigler et al., 2009; Engle et al., 2010). Also, mean TGM concentrations of 1.72 and $1.66 \mathrm{ng} \mathrm{m}^{-3}$ were obtained from long-term measurements at Mace Head, Ireland and Zingst, Germany, respectively (Kock et al., 2005). Recently, many efforts have been devoted to model the spatial distributions of atmospheric $\mathrm{Hg}$ in Asia, mainly because this region constitutes of a very important portion of the global total anthropogenic Hg emissions (Seigneur et al., 2004; Selin et al., 2007; Lin et al., 2010). These modeling studies predicted relatively high surface ambient TGM concentrations in Eastern China and areas downwind Eastern China, which are consistent with many of the observations (Feng et al., 2005; Fu et al., 2010a, b; Ci et al., 2011). However, according to this 

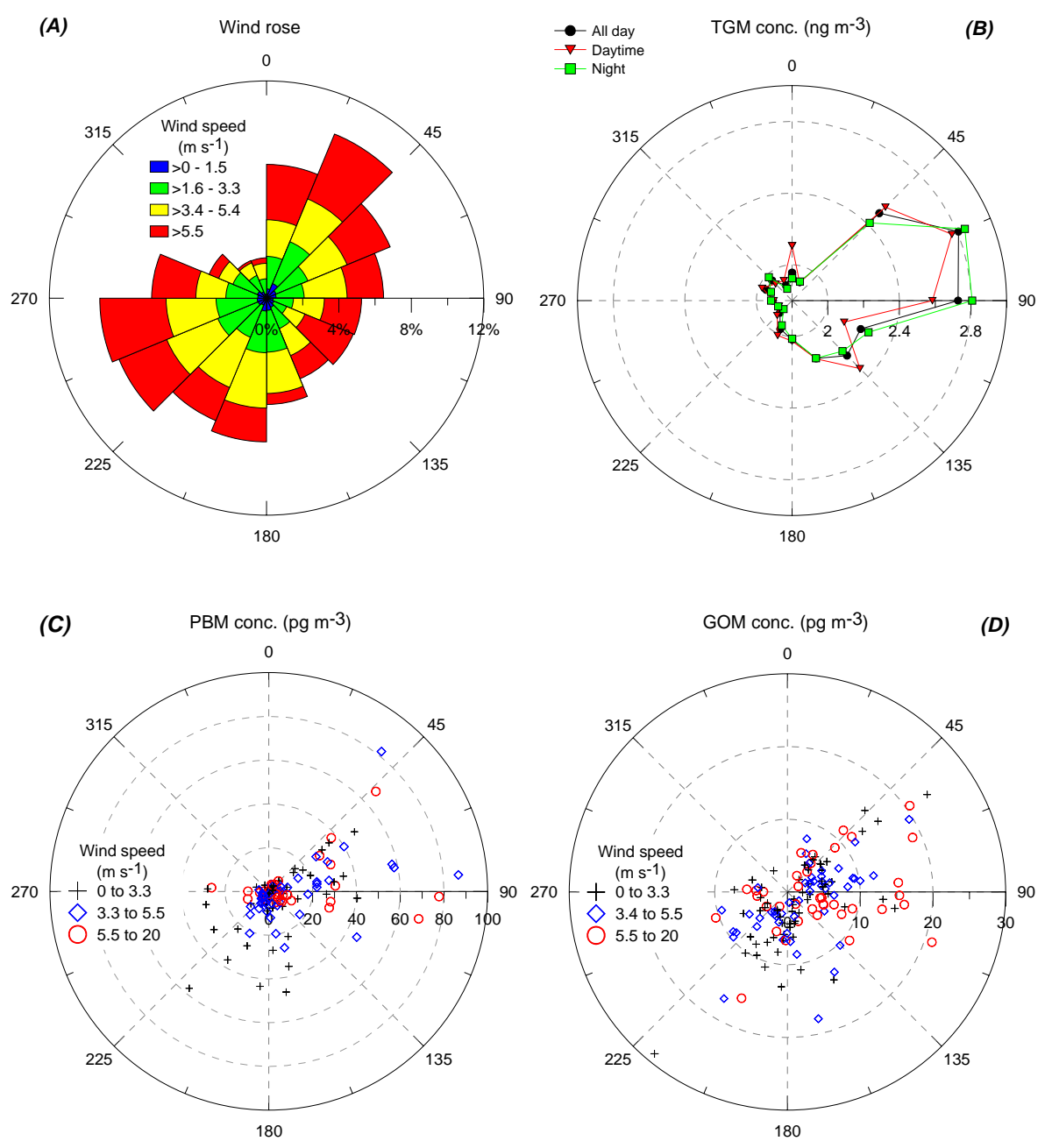

Fig. 4. (A) Wind rose for the entire study period; (B) wind rose for TGM; (C) wind rose for all PBM data sets; and (D) wind rose for all GOM data sets.

work, most of the modeling results underestimated the atmospheric TGM levels in the northeast of Tibetan Plateau. As a persistent atmospheric pollutant, atmospheric TGM (predominant in the form of $\mathrm{Hg}^{0}$ ) emitted from the central and east of China could undergo long-range transport to Western China, which was likely responsible for the elevated TGM levels observed at WLG. Moreover, India is also an increasing anthropogenic $\mathrm{Hg}$ emission source region (Pirrone et al., 2010). Long-range transport of $\mathrm{Hg}$-enriched air masses originated from and/or passed over India was likely an additional contributor to atmospheric $\mathrm{Hg}$ at WLG.

\subsection{Wind dependence of atmospheric $\mathrm{Hg}$ species at WLG}

Annual wind rose at WLG is shown in Fig. 4a. Most of the wind sectors were abundant $(>5 \%)$ with northeast and southwest as the prevailing wind directions. Wind from east was originated from and/or passed over low altitude ar- eas in Northwestern China; whereas western wind was normally from Tibetan Plateau and Xinjiang province with relatively lower $\mathrm{Hg}$ emission intensity. Speciated atmospheric $\mathrm{Hg}$ showed a strong dependence on wind direction at WLG. As shown in Fig. 4b, winds from south, west, and north all showed much lower TGM concentrations compared to winds from northeast and east directions. The mean TGM concentrations for south, west, and north wind sectors were all in the range of $1.8 \sim 2.0 \mathrm{ng} \mathrm{m}^{-3}$, which was slightly higher than the values observed in remote areas in Northern Hemisphere (Lindberg et al., 2007). In contrast, the mean TGM concentrations for northeast and east wind sectors were in the range of $2.49 \sim 2.81 \mathrm{ng} \mathrm{m}^{-3}$, which were $23 \sim 46 \%$ higher than those observed for south, west, and north wind sectors.

PBM and GOM also showed pronounced dependence on wind direction at WLG. As shown in Fig. 4c, most $(\sim 80 \%)$ of the high PBM concentrations (above the 90th percentile value) were observed under northeasterly to southeasterly flows; whereas air masses from west to north sectors showed 


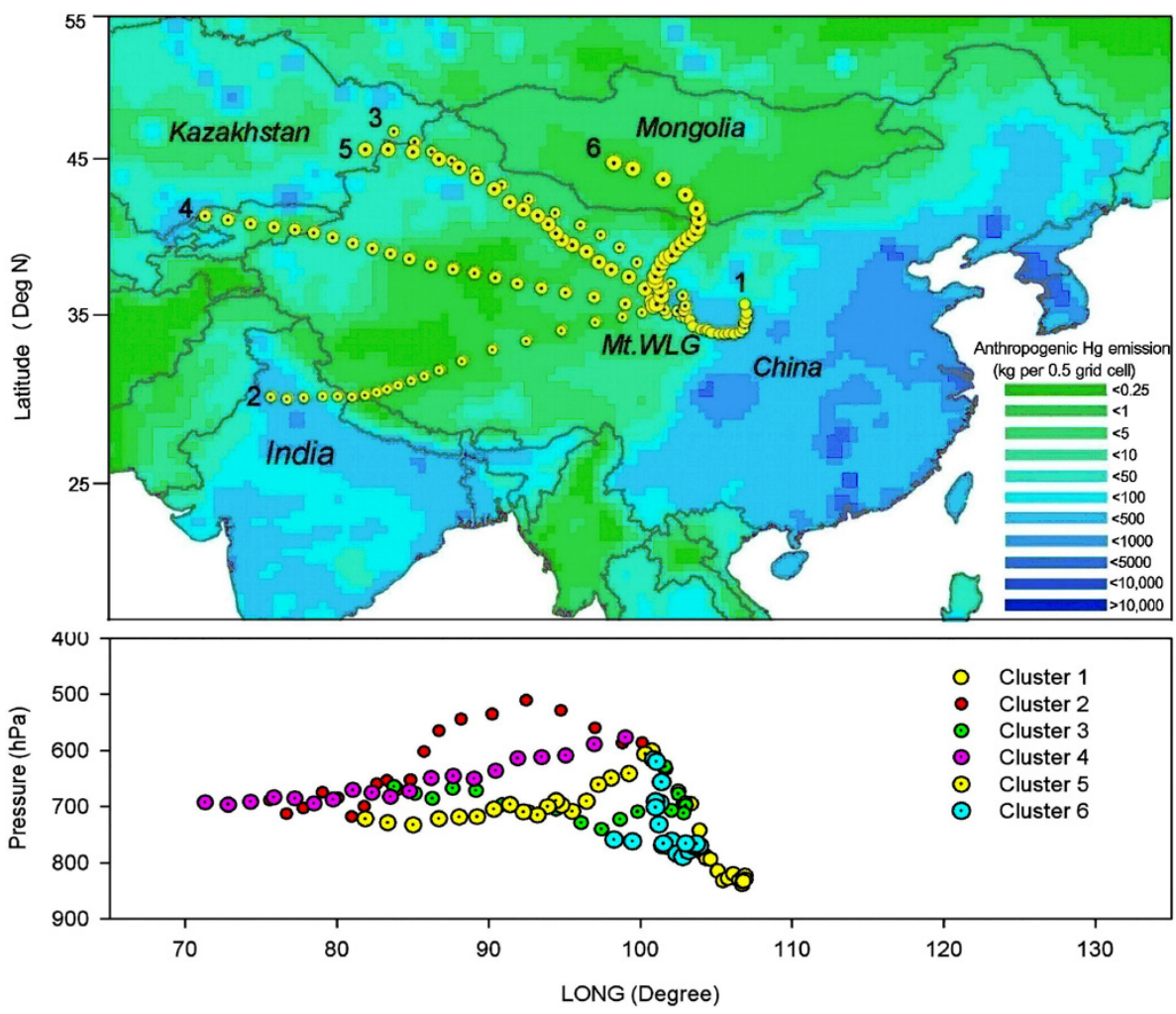

Fig. 5. Five-day mean trajectory clusters ended at WLG and the spatial distributed inventories of anthropogenic Hg emission in Asia (Pacyna et al., 2005). The circles on the clusters represent 6-h intervals.

the concentrations normally lower than $10 \mathrm{pg} \mathrm{m}^{-3}$. GOM showed a similar but less pronounced directional dependence compared to PBM (Fig. 4 d). $\sim 73 \%$ of the high GOM events (above 90th percentile value) were observed under northeasterly to southeasterly flows.

The strong directional dependence of atmospheric $\mathrm{Hg}$ species at WLG corresponded very well with the regional distributions of anthropogenic $\mathrm{Hg}$ sources. Qinghai province, in which the sampling is located, is one of the lowest anthropogenic $\mathrm{Hg}$ sources regions in China. Wu et al. (2006) estimated that the total annual anthropogenic $\mathrm{Hg}$ emission in Qinghai province was $1.9 \mathrm{t}$, only accounting for $0.27 \%$ of the total anthropogenic emissions in China. However, most (>90\%) of the emissions were originated from areas around the Xining city, which is situated $\sim 90 \mathrm{~km}$ northeast to WLG. Besides, it also showed that area around Lanzohu, the capital of Gansu province which situates $\sim 260 \mathrm{~km}$ east to the WLG, was also an important source region. These two source regions were likely responsible for the elevated atmospheric $\mathrm{Hg}$ species observed under the northeastern and eastern flow. Interestingly, there were relatively larger differences of TGM concentrations between night and daytime under northeasterly to southeasterly flows than westerly flows. For the easterly flow, the night mean TGM concentrations were $2.8 \sim 8.6 \%$ higher than those during daytime. As the sampling site directly received more long-range transport air masses during night (we discuss this more in Sect. 3.4), once again, this indicates the impact of long-range transport of $\mathrm{Hg}$ from urban and industrial areas to the east of the sampling site. On the other hand, the night mean TGM concentrations were generally $0 \sim 3 \%$ lower than those during daytime when air masses were originated from areas south, west, and north to the sampling site, in which there might be minor sources related to the regional human activities.

\subsection{Implications of atmospheric $\mathrm{Hg}$ budget in China and other Asian countries}

In general, levels of atmospheric $\mathrm{Hg}$ in air masses are closely related to its original areas and transport pathways. Therefore, the relatively levels and emission rate of atmospheric $\mathrm{Hg}$ in different regions could be roughly estimated using backward trajectories analysis and TGM concentrations at a receptor station. In this study, all the backward trajectories with starting height of $1000 \mathrm{~m}$ above ground level (using trajectories with different starting heights did not significantly alter cluster results) were grouped into 6 clusters using a hierarchical Ward's method (Wang et al., 2009). Figure 5 shows the result of the cluster analysis and anthropogenic $\mathrm{Hg}$ emissions in 2000 (Pacyna et al., 2005). Cluster 1 represents air masses originated from Western China and passing over 


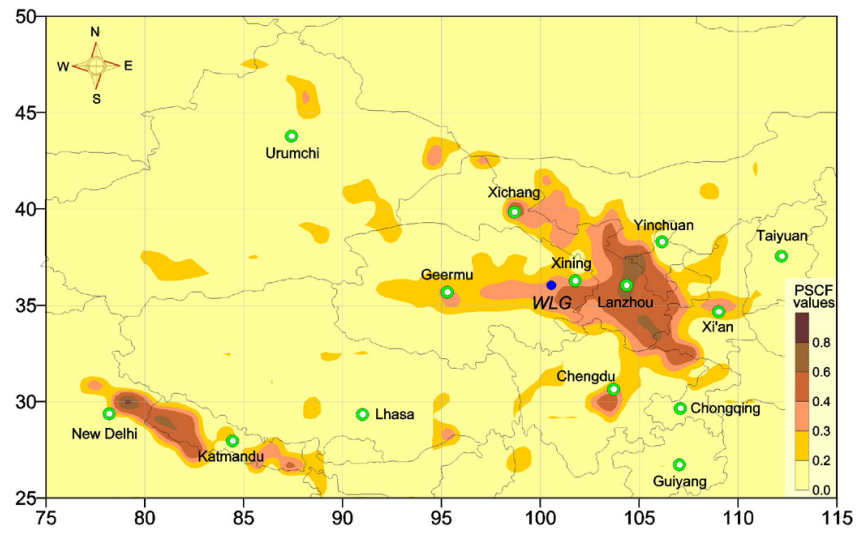

Fig. 6. Likely source areas of TGM identified using Potential Source Contribution Function (PSCF) plots.

several urban areas of Western China with relatively lower traveling height. Cluster 2 shows air masses originated from Northwest India and passing over Tibetan Plateau with relatively higher traveling height. Cluster 3, 4, and 5 were all originated from Middle Asia but with different pathways, with cluster 3 passing over north of the Xinjiang, northwest of Gansu, and east of Qinghai, cluster'4 passing over Taklimakan Desert and northern Tibetan Plateau, and cluster 5 passing over north of the Xinjiang province and northwest of Gansu province. Cluster 6 indicates air masses coming from Mongolia and passing over the west of Inner Mongolia and middle of Gansu province.

In order to minimize the effects of upslope wind which generally captures pollutants from the surrounding regions, only nighttime mean TGM concentrations were used to calculate mean TGM concentrations related to the 6 clusters. For the 6 clusters, cluster 2 was observed with the highest mean TGM concentration of $2.46 \mathrm{ng} \mathrm{m}^{-3}$. Since Tibetan Plateau where cluster 2 passed over was pristine area and seldom reported with any major $\mathrm{Hg}$ emission sources (Fig. 5), the elevated TGM level of cluster 2 was mostly likely a reflection of pollution with respect to atmospheric $\mathrm{Hg}$ in Northwest India. As a fast developing country, anthropogenic $\mathrm{Hg}$ emission in India has attracted an increasing attention in recent years. It was reported that the annual anthropogenic $\mathrm{Hg}$ emissions of India in 2004 was about $240 \mathrm{t}$, with most derived from coal combustion, waste disposal, and non-ferrous smelting activities. Northwestern India, where the capital of New Delhi is located, is generally characterized by high population density and many industrial centres, which may have high $\mathrm{Hg}$ emission rate and elevated atmospheric $\mathrm{Hg}$ levels.

TGM concentrations of cluster 1 were also elevated with a mean value of $2.31 \mathrm{ng} \mathrm{m}^{-3}$. This is mainly because air masses of cluster 1 passed over several industrial centers and urban areas in northwest of China, such as Xi' an, Lanzhou, and Xining. Cluster 3 and cluster 4 showed the two lowest mean TGM levels of $1.93 \mathrm{ng} \mathrm{m}^{-3}$ and $1.81 \mathrm{ng} \mathrm{m}^{-3}$, respec- tively. This indicates relatively low intensity of $\mathrm{Hg}$ emission in Middle Asia, Xinjiang, and west Inner Mongolia. Cluster 5 showed relatively higher TGM concentrations compared to cluster 3 , with a mean value of $2.11 \mathrm{ng} \mathrm{m}^{-3}$. Air masses in cluster 3 and cluster 5 were originated from east of Kazakhstan and both passed over north of Xinjiang province, but they had different pathways before ending at WLG. The elevated mean TGM concentration of cluster 5 probably indicates $\mathrm{Hg}$ emissions in the middle of Gansu province. Mean TGM concentrations related to air masses in cluster 6 was $2.04 \mathrm{ng} \mathrm{m}^{-3}$, indicating Mongolia and west of Inner Mongolia had low atmospheric $\mathrm{Hg}$ emission intensity.

It should be pointed out that using TGM concentrations at a receptor station and cluster analysis might over or underestimate regional atmospheric $\mathrm{Hg}$ budgets. In general, air masses originated from polluted areas could be diluted during transport over the low $\mathrm{Hg}$ emission regions, and this generally predicts relatively lower levels of $\mathrm{Hg}$ in the source areas; whereas air masses originated from pristine areas might be disturbed by $\mathrm{Hg}$-enriched upflows. In this study, we suggest that atmospheric $\mathrm{Hg}$ level in Northwestern India might be underestimated by the cluster analysis.

\subsection{PSCF results}

Figure 6 shows the possible source regions and pathways of atmospheric TGM at WLG identified by the PSCF analysis. As shown in Fig. 6, eastern Qinghai, eastern Gansu, western Shanxi, and western Ningxia Province were likely source regions of atmospheric TGM at WLG. This is mainly because these areas are important anthropogenic $\mathrm{Hg}$ source regions in Western China, and also important source regions and pathway of air masses ended at WLG. It was estimated that the anthropogenic $\mathrm{Hg}$ emissions in Qinghai and Gansu provinces were 5.7 and 28.7 tons in 2003, respectively, with most of their sources located in the east of the two provinces ( $\mathrm{Wu}$ et al., 2006; Shetty et al., 2008). Northwestern India was also an important source region to WLG (Fig. 6). As discussed in Sect. 3.3, Northwestern India is an important urbanized and industrialized area and might be of high anthropogenic $\mathrm{Hg}$ emission rates, and air masses originated from this area probably climbed over the Tibetan Plateau and contributed to $\mathrm{Hg}$ pollution to the northeastern Tibetan Plateau.

The PSCF result in Fig. 7a indicates southeastern Qinghai province and Northwestern India were likely important source regions and pathways for atmospheric PBM at WLG. The identified area in southeastern Qinghai province was probably due to the fact that there are several settlements located in this area, which might contribute to PBM emissions. Also, this area is normally characterized by yellow soil landforms, and a small desert is located about $60 \mathrm{~km}$ south to the WLG site, which might yield gas-to-particle productions of PBM during atmospheric transport. A small region in Northwestern India was also identified as a potential source region and pathways for PBM at WLG, and this is in good 
Table 1. Summary of speciated $\mathrm{Hg}$ concentrations and meteorological parameters from September 2007 to September 2008 at WLG.

\begin{tabular}{|c|c|c|c|c|c|c|c|c|c|}
\hline & \multicolumn{2}{|c|}{ TGM $\left(\mathrm{ng} \mathrm{m}^{-3}\right)$} & \multicolumn{2}{|c|}{$\mathrm{PBM}\left(\mathrm{pg} \mathrm{m}^{-3}\right)$} & \multicolumn{2}{|c|}{ GOM $\left(\mathrm{pg} \mathrm{m}^{-3}\right)$} & \multirow{2}{*}{$\begin{array}{l}\text { Air temperature } \\
\left({ }^{\circ} \mathrm{C}\right)\end{array}$} & $\begin{array}{l}\text { Humidity } \\
(\%)\end{array}$ & \multirow{2}{*}{$\begin{array}{l}\text { Wind speed } \\
\left(\mathrm{m} \mathrm{s}^{-1}\right)\end{array}$} \\
\hline Spring & $\begin{array}{l}\text { Mean* } \pm \sigma \\
1.83 \pm 0.78\end{array}$ & $\begin{array}{l}\text { Range } \\
0.69-12.1\end{array}$ & Mean $\pm \sigma$ & $\begin{array}{l}\text { Range } \\
-\end{array}$ & $\begin{array}{l}\text { Mean } \pm \sigma \\
-\end{array}$ & $\begin{array}{l}\text { Range } \\
-\end{array}$ & & 27.4 & \\
\hline Summer & $2.00 \pm 0.77$ & $1.01-11.7$ & $5.2 \pm 5.3$ & $0.2-28.5$ & $7.4 \pm 4.3$ & $1.7-21.0$ & 6.71 & 61.6 & 4.65 \\
\hline Autumn & $1.96 \pm 0.70$ & $0.92-8.48$ & $30.8 \pm 22.0$ & $1.3-82.1$ & $9.5 \pm 6.5$ & $2.2-28.8$ & -0.92 & 48.8 & 4.31 \\
\hline Winter & $2.15 \pm 1.40$ & $0.94-12.8$ & $22.1 \pm 18.3$ & $0.9-86.9$ & $5.2 \pm 2.7$ & $1.5-15.4$ & -12.05 & 28.5 & 4.34 \\
\hline Total & $1.98 \pm 0.98$ & $0.69-12.8$ & $19.4 \pm 18.1$ & $0.2-86.9$ & $7.4 \pm 4.8$ & $1.5-28.8$ & -1.68 & 41.6 & 4.59 \\
\hline
\end{tabular}

* Geometric mean is used because TGM followed log normal distribution pattern.

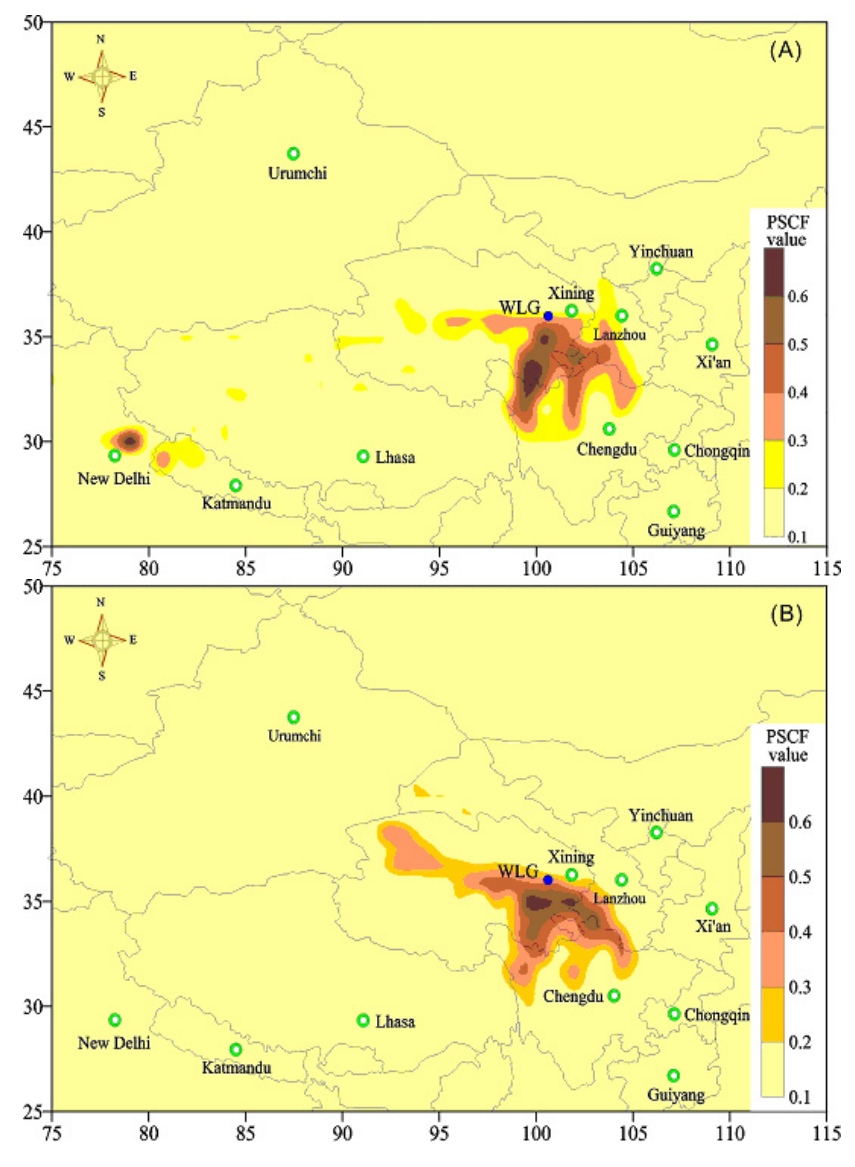

Fig. 7. Likely source areas of (A) PBM and (B) GOM identified using Potential Source Contribution Function (PSCF) plots.

accordance with TGM. The high PSCF values in Northwestern India were mainly due to the fact that many high PBM events were associated with trajectories originated or passed over Northwestern India (33 trajectories).

Compared to TGM and PBM, the regional sources might play a more pronounced role in the distribution of GOM in ambient air at WLG. As shown in Fig. 7b, the most possible source region and pathway for GOM at WLG is located

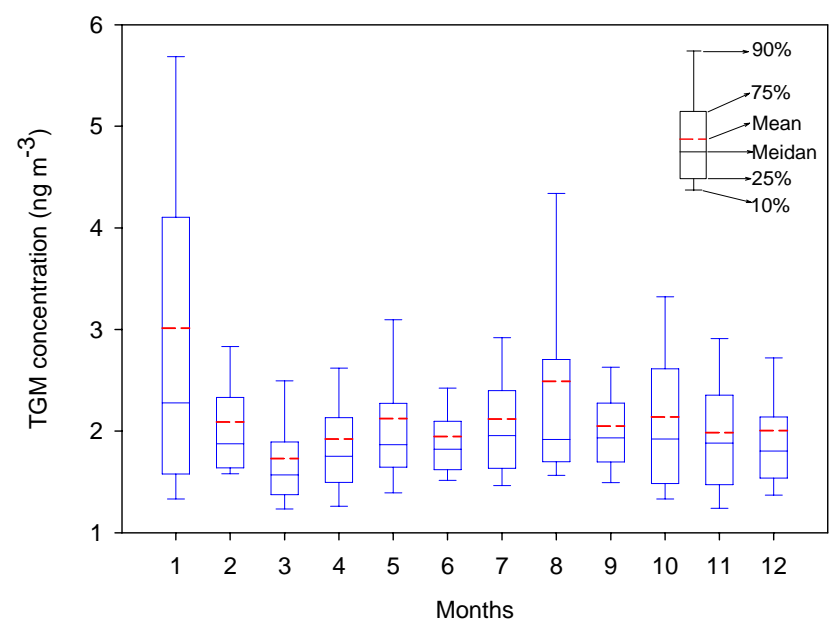

Fig. 8. Monthly variations of TGM concentrations in ambient air at Mount Waliguan Observatory Baseline.

about $70 \mathrm{~km}$ south to the sampling site, and no significant long-range transport processes contributed to the GOM at WLG. The area with the highest PSCF values located south to the sampling site might be partially related to GOM emissions from several settlements mentioned above. However, it should be pointed out that many uncertainties are related to the PSCF analysis for PBM and GOM. First of all, due to the relatively short sampling period for PBM and GOM, the PSCF results for PBM and GOM are less accurate compared to TGM. Also, it is commonly known that in situ production via photochemical oxidation is also important source for atmospheric GOM in remote areas (Lindberg and Stratton, 1998; Lynam and Keeler, 2005; Sigler et al., 2009). Due to the trailing effects of PSCF analysis (Han et al., 2005), the contributions from areas located upwind the dominant wind direction of the sampling site were likely overestimated.

\subsection{Seasonal variations}

Monthly variation of TGM concentrations in ambient air at WLG was shown in Fig. 8. The highest monthly mean TGM concentration, $2.99 \mathrm{ng} \mathrm{m}^{-3}$, was observed in January 2008, 


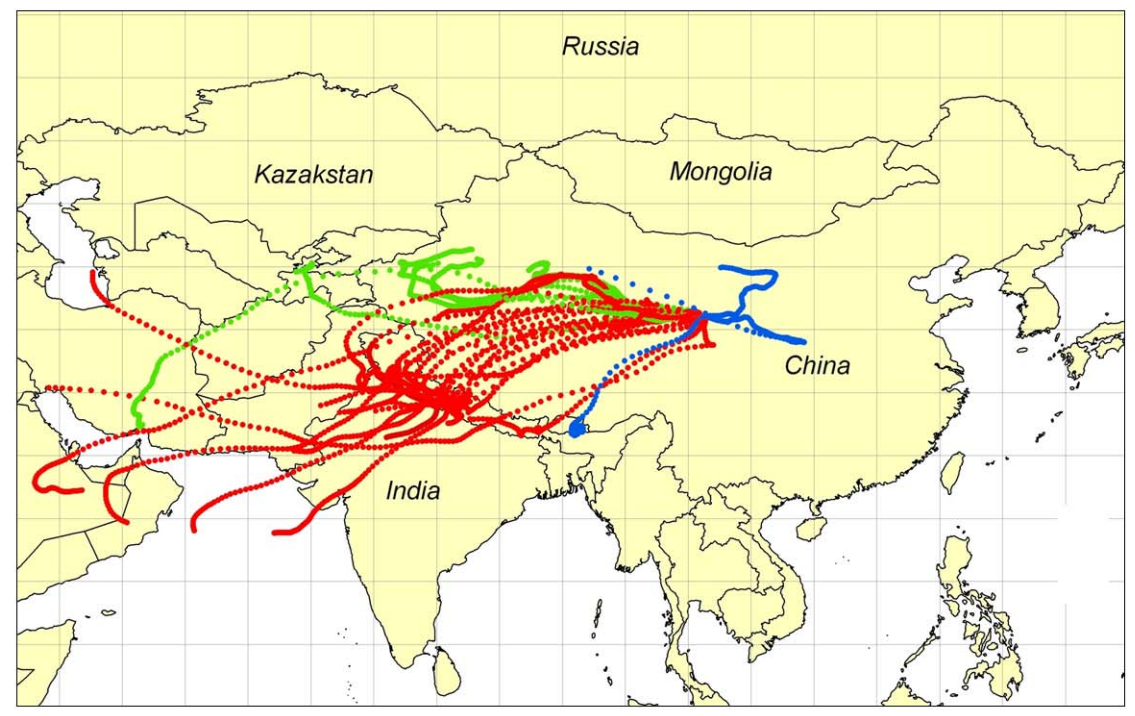

Fig. 9. Daily backward trajectories ended at WLG at a height of $1000 \mathrm{~m}$ above ground in January 2008 .

while the lowest monthly mean value of $1.73 \mathrm{ng} \mathrm{m}^{-3}$ was observed in March 2008. Aside from January 2008, TGM concentrations at WLG showed a clear trend with relatively higher monthly means in summer and autumn and lower monthly means in spring and winter (Fig. 8). This trend is in contrast to most of the previous observations conducted in the east and southwest of China generally with high monthly means in cold seasons and low monthly means in warms seasons (Feng et al., 2002, 2004; Fu et al., 2008a, 2010a, 2011b; Sheu et al., 2010). Unlike previous studies which generally highlighted the impact of local and regional emissions from combustion sources on the seasonal TGM variations, long-range transport played an important role in regulating the monthly variations of TGM at WLG. The highest monthly mean TGM concentration observed in January 2008 was likely caused by long-range transport of pollutions from Northern India. Figure 9 shows daily backward trajectories at WLG in January 2008, and it is clear that most of the air masses $(>70 \%)$ were originated from or passed over Northern India. These air masses likely captured Hgenriched plumes from boundary layer of Northern India and contributed to the elevated TGM concentrations. For other months, monthly variations of TGM were mainly affected by the plateau monsoon, which is generated by the thermaldynamic and kinetic effects of Tibetan Plateau. The plateau monsoon generally brings northeasterly to easterly flows during warm seasons and southwesterly to northwesterly flows during cold seasons. As discussed in Sects. 3.2 and 3.3, due to the anthropogenic $\mathrm{Hg}$ emissions in Northwestern China, air flows from northeast to east directions generally showed elevated TGM concentrations, which was probably responsible for the elevated TGM concentrations in warm seasons.
Due to the relatively short sampling periods and large variations of PBM and GOM, our data are too limited to depict clear seasonal variations. As shown in Table 1, PBM concentrations varied significant among the three sampling campaigns, with much higher concentrations in autumn and winter, and lower concentrations in summer. Correlation analysis between PBM and TGM showed a significant linear correlation in winter sampling campaign $(r=0.66, p<0.01)$, and a week correlation in autumn $(r=0.05, p=0.77)$ and summer $(r=0.07, p=0.57)$, respectively. This indicates that PBM might have a major source of long-range transport of pollution from Northern India as that of TGM. For other months, processes including the regional sources, wet and dry depositions, as well as long-rang transport might play a combined role in controlling the seasonal variation of PBM. GOM showed the highest mean value during autumn, which is similar to PBM (Table 1). A significant correlation $(r=0.45, p<0.05)$ between GOM and PBM concentrations was observed during this sampling campaign. Higher GOM concentrations were mostly observed under northeasterly to easterly flow patterns during autumn sampling campaign. This may suggest the impact of regional emissions. The lowest mean value of GOM $\left(5.2 \mathrm{pg} \mathrm{m}^{-3}\right)$ was observed in winter sampling campaign (January 2008), during which mean TGM concentration reached up to $4.07 \mathrm{ng} \mathrm{m}^{-3}$. As discussed previously, elevated TGM and PBM concentrations in January 2008 were mostly likely resulted from long-range transport from Northern India. However, due to the much short residence time in the atmosphere, long-range transport from Northern India could not affect GOM distribution at the sampling site. The prevalent wind during this period was from south to southwest of the sampling site which had low regional emissions, which might explain the lower levels of GOM. 


\subsection{Diurnal variation}

TGM concentrations showed a clear diurnal trend at WLG. As shown in Fig. 10, the minimum TGM concentrations occurred in the afternoon, and then tended to increase through afternoon and early night to a night peak at $\sim 22: 00$. During night, TGM concentrations remained at a relatively constant level, and then increased fast to a morning peak just prior to the sunrise, followed by a significant decline through morning and early afternoon. Overall, TGM concentrations at WLG showed relatively higher values during night. This trend is in contrast to most of the previous observations at remote mountainous areas of China (Fu et al., 2008a, 2010a, 2012; Sheu et al., 2010). These studies reported relatively higher levels of TGM during daytime, which was mainly related to the increased impact of regional sources via upslope transport. WLG was also affected by diurnal alternations of mountain valley breezes. During daytime, upslope wind generally brings air flows from surrounding low altitude areas, while the vertical air flow movement reverses during night, which results in downward transport of the free troposphere air. The observed TGM peak before mid-night and relatively higher nighttime TGM concentrations probably indicates a strong impact of long-range transport at the sampling site.

The TGM peak in the morning corresponded very well with the lowest wind speed and air temperature, as well as the highest air humidity. It is supposed that, due to the low wind speeds, replenishment of fresh air tended to decrease, which might result in accumulations of pollutants at the sampling site. Additionally, there are several settlements which might related to $\mathrm{Hg}$ emissions in the surrounding area of WLG. This probably yielded an accumulation of atmospheric TGM during the whole night under a stable nocturnal boundary layer. We examined the wind dependence of TGM during the morning peak (7:00 9:00) and found that all the wind flows from south to north directions exhibited relatively higher TGM concentrations compared to the result based on the whole data sets (not shown). Clearly, TGM trapped below the boundary layer of surrounding areas was probably an additional contributor to the morning peak following the upslope flows.

PBM concentrations at WLG showed a relatively higher level before mid-night (Fig. 11), which is consistent with the diurnal pattern of TGM, indicating impacts from long-range transport. The relatively lower level, however, was observed during the night (Fig. 11). We suppose that, except the impact of long-range transport, regional sources also played an important role in PBM levels at WLG. Diurnal pattern of GOM at WLG was characterized by relatively higher levels between midday and early afternoon and lower levels during night (Fig. 11), likely reflecting in-situ photochemical productions and/or regional sources. This diurnal pattern is in contrast to some observations conducted at high-elevation sampling sites, which showed elevated RGM concentrations during night due to the downslope flows from free tropo-

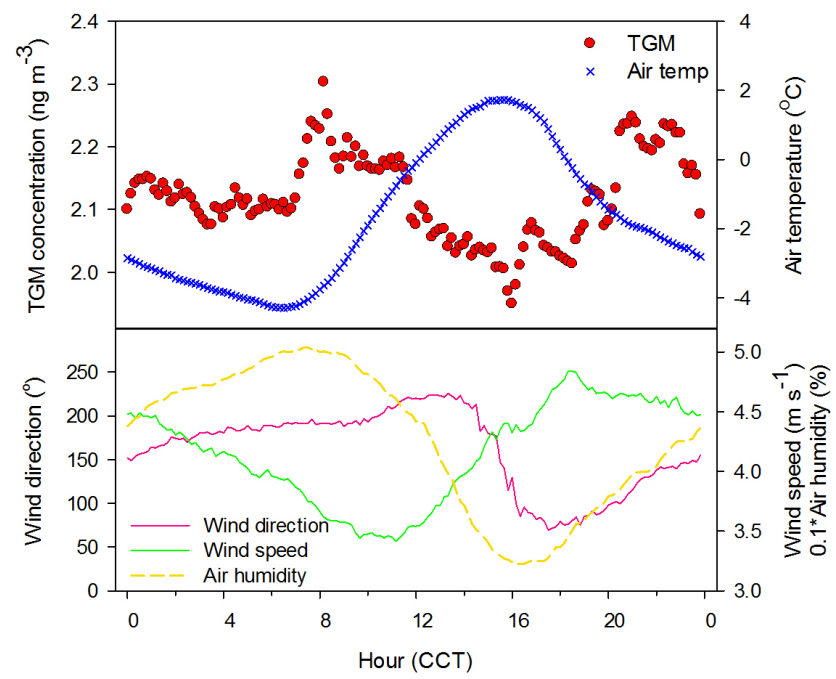

Fig. 10. Diurnal variation of TGM concentration in ambient air and meteorological parameters at WLG during the whole study period.

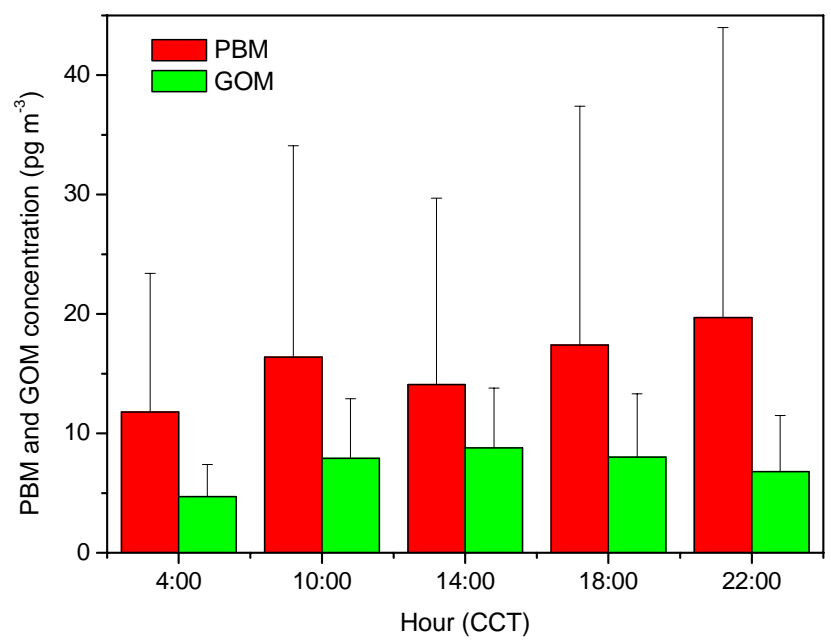

Fig. 11. Diurnal trends of PBM and GOM concentrations in ambient air at Mount Waliguan Observatory Baseline.

sphere or upper troposphere (Swartzendruber et al., 2006; Sheu et al., 2010), but it is consistent with previous studies conducted in the Rocky Mountains (Faïn et al., 2009) and Nevada (Weiss-Penzias et al., 2009) in USA. Since WLG generally receives air flows from free troposphere during night, the relatively lower nighttime GOM concentrations at WLG indicates there might be no strong enrichment of GOM in the free troposphere during the study period, or the downslope flows at WLG during the study period were originated from or travelled in relatively lower layer of free troposphere. Since there are many high-elevation mountaintops (higher than $4000 \mathrm{~m}$ a.s.l) around the WLG and the average altitude in the study area is generally higher than $3000 \mathrm{~m}$ a.s.l., the intrusion of air flows from free troposphere and upper 
troposphere is not expected to be strong at WLG. Besides, the site of WLG is situated in inland areas of China, and this is different from the sites in the Mount Bakelor in USA (Swartzendruber et al., 2006) and the Mt. Front Lulin in Taiwan (Sheu et al., 2010) which are situated closely to Ocean. It may have relatively lower concentrations of atmospheric oxidants (e.g. Reactive Halogens, Ozone) and low productions of GOM in the lower free troposphere (Swartzendruber et al., 2006; Obrist et al., 2010; Sheu et al., 2010).

\section{Conclusions}

Continuously automated monitoring of atmospheric TGM and manual measurements of PBM and GOM at selected seasons was performed at Waliguan GAW Baseline Observatory from September 2007 to September 2008. Mean concentrations of TGM, PBM and GOM during the entire study were $1.98 \pm 0.98 \mathrm{ng} \mathrm{m}^{-3}, 19.4 \pm 18.1 \mathrm{pg} \mathrm{m}^{-3}$, and $7.4 \pm 4.8 \mathrm{pg} \mathrm{m}^{-3}$, respectively. Levels of speciated $\mathrm{Hg}$ at WLG were slightly higher than those observed from the remote areas in Europe and North America, indicating relatively high regional mercury budget in Western China. Mean TGM concentration at WLG was much lower than those observed at remote sites in Southwestern China, which were impacted by strong regional anthropogenic sources; while it is relatively higher than the mean value at Mt. Changbai, Northwestern China. The overall regional atmospheric TGM distribution corresponds very well with the regional anthropogenic $\mathrm{Hg}$ emissions.

On the basis of backward trajectories analysis, we found most of the air masses with high TGM concentrations at WLG were originated from or passed over urban and industrial areas in Western China, as well as Northern India; whereas air masses with low TGM concentrations were mostly from Middle Asia, Xinjiang and Tibetan Pleteau. The PSCF results clearly identified eastern Gansu, eastern Qinghai, western Shanxi and Ningxia as potential sources regions of WLG. Additionally, Northern India was also an important source region of WLG. Regional sources which contributed to WLG were mostly located to the east of WLG, which might include Xining city and other major settlements to the east of WLG.

TGM concentrations showed the highest monthly mean concentration in January 2008, which was mainly caused by the long-range transport of $\mathrm{Hg}$ from Northern India. For other months, the alternation of plateau monsoon played a major role in the TGM distribution. In warm months, air flows from low-altitude areas to the east of WLG became prevalent, which resulted in relatively higher monthly mean TGM concentrations; while during cold seasons, the prevalent air flows from Tibetan generally generated lower monthly means. PBM and GOM showed different seasonal variations, with more pronounced effects from the regional sources. TGM concentrations showed a clear diurnal pattern with relatively higher concentrations during night, which indicates the impact of long-range transport. The diurnal pattern of PBM was characterized by relatively higher concentrations before mid-night and afternoon, indicating the combined effect from regional sources and long-range transport. GOM showed a diurnal trend with high concentrations in daytime, likely reflecting in-situ photochemical productions and/or regional sources.

Acknowledgements. This research was financially supported by the Knowledge Innovative Project (Special Foundation for Young Sciences) of the Chinese Academy of Science (KZCX2-EWQN-111), and also funded by the National Science Foundation of China (41003051, 40973086) and the West Light Foundation of the Chinese Academy of Science. The author would like to acknowledge Landis from US Environment Protection Agency for offering denuders and auxiliary parts. We also thank the Waliguan Baseline Observatory for offering the monitoring platform and all the staff of the station for their sampling assistance.

Edited by: R. Ebinghaus

\section{References}

Ci, Z. J., Zhang, X. S., Wang, Z. W., Niu, Z. C., Diao, X. Y., and Wang, S. W.: Distribution and air-sea exchange of mercury (Hg) in the Yellow Sea, Atmos. Chem. Phys., 11, 2881-2892, doi:10.5194/acp-11-2881-2011, 2011.

Choi, H. D., Holsen T. M., and Hopke, P. K.: Atmospheric mercury $(\mathrm{Hg})$ in the Adirondacks: Concentrations and sources, Environ. Sci. Technol., 42, 5644-5653, 2008.

Cobbett, F. D., Steffen, A., Lawson, G., and Heyst, H. J. V.: GEM fluxes and atmospheric mercury concentrations (GEM, RGM and $\mathrm{Hg}^{p}$ ) in the Canadian Arctic at Alert, Nunavut, Canada (February-June 2005), Atmos. Environ., 41, 6527-6543, 2007.

Ebinghaus, R., Jennings, S. G., Kock, H. H., Derwent, R. G., Manning, A. J., and Spain, T. G.: Decreasing trends in total gaseous mercury observations in baseline air at Mace head, Ireland from 1996 to 2009, Atmos. Environ., 45, 3475-3480, 2011.

Engle, M. A., Tate, M. T., Krabbenhoft, D. P., Schauer, J. J., Kolker, A., Shanley, J. B., and Bothner, M. H.: Comparison of atmospheric mercury speciation and deposition at nine sites across central and eastern North America, J. Geophys. Res., 115, D18306, doi:10.1029/2010JD014064, 2010.

Faïn, X., Obrist, D., Hallar, A. G., Mccubbin, I., and Rahn, T.: High levels of reactive gaseous mercury observed at a high elevation research laboratory in the Rocky Mountains, Atmos. Chem. Phys., 9, 8049-8060, doi:10.5194/acp-9-8049-2010, 2010.

Feng, X., Sommar, J., Lindqvist, O., and Hong, Y.: Occurrence, emissions and deposition of mercury during coal combustion in the province Guizhou, China, Water Air Soil Pollut., 139, 311324, 2002.

Feng, X., Tang, S., Shang, L., Yan, H., Sommar, J., and Lindqvist, O.: Total gaseous mercury in the air of Guiyang, PR China, Sci. Total Environ., 304, 61-72, 2003.

Feng, X., Shang, L., Wang, S., Tang, S., and Zheng, W.: Temporal variation of total gaseous mercury in the air of Guiyang, China, J. Geophys. Res., 109, D03303, doi:10.1029/2003JD004159, 2004. 
Fu, X. W., Feng, X. B., Zhu, W. Z., Wang, S. F., and Lu, J.: Total gaseous mercury concentrations in ambient air in the eastern slope of Mt. Gongga, South-Eastern fringe of the Tibetan plateau, China, Atmos. Environ., 42, 970-979, 2008a.

Fu, X. W., Feng, X. B., Zhu,W. Z., Zheng,W.,Wang, S. F., and Lu, J. Y.: Total particulate and reactive gaseous mercury in ambient air on the eastern slope of the Mt. Gongga area, China, Appl. Geochem., 23, 408-418, 2008b.

Fu, X. W., Feng, X., Dong, Z. Q., Yin, R. S., Wang, J. X., Yang, Z. R., and Zhang, H.: Atmospheric gaseous elemental mercury (GEM) concentrations and mercury depositions at a high-altitude mountain peak in south China, Atmos. Chem. Phys., 10, 24252437, doi:10.5194/acp-10-2425-2010, 2010a.

Fu, X. W., Feng, X., Zhang, G., Xu, W., Li, X., Yao, H., Liang, P., Li, J., Sommar, J., Yin, R., and Liu, N.: Mercury in the marine boundary layer and seawater of the South China Sea: Concentrations, sea/air flux, and implication for land outflow, J. Geophys. Res., 115, D06303, doi:10.1029/2009JD012958, 2010b.

Fu, X. W., Feng, X. B., Qiu, G. L., Shang, L. H., and Zhang, H.: Speciated atmospheric mercury and its potential source in Guiyang, China, Atmos. Environ., 45, 4205-4212, 2011.

Fu, X. W., Feng, X., Shang, L. H., Wang, S. F., and Zhang, H.: Long-term monitoring of atmospheric total gaseous mercury (TGM) at a remote site in Mt. Changbai area, northeastern China, Atmos. Chem. Phys. Discuss., 12, 4417-4446, doi:10.5194/acpd-12-4417-2012, 2012.

Gustin, M. and Jaffe, D.: Reducing the uncertainty in measurement and understanding of mercury in the atmosphere, Environ. Sci. Technol., 44, 2222-2227, 2010.

Han, Y. J., Holsen, T. M., Hopke, P. K., and Yi, S. M.: Comparison between back-trajectory based modeling and lagrangian backward dispersion modeling for locating sources of reactive gaseous mercury, Environ. Sci. Technol., 39, 1715-1723, 2005.

Kellerhals, M., Beauchamp, S., Belzer, W., Blanchard, P., Froude, F., Harvey, B., McDonald, K., Pilote, M., Poissant, L., Puckett, K., Schroeder, B., Steffen, A., and Tordon, R.: Temporal and spatial variability of total gaseous mercury in Canada: results from the Canadian Atmospheric Mercury Measurement Network (CAMNet), Atmos. Environ., 37, 1003-1011, 2003.

Kim, E., Hopke, P. K., Henski, M., and Koerber, M.: Source of fine particles in a rural Midwestern U.S., area, Environ. Sci. Technol., 39, 4953-4960, 2005.

Kock, H. H., Bieber, E., Ebinghaus. R., Spain, T. G., and Thees, B.: Comparison of long-term trends and seasonal variations of atmospheric mercury concentrations at the two European coastal monitoring stations Mace Head, Ireland and Zingst, Germany, Atmos. Environ., 39, 7549-7556, 2005.

Landis, M. S., Stevens, R. K., Schaedlich, F., and Prestbo, E. M.: Development and Characterization of an Annular Denuder Methodology for the Measurement of Divalent Inorganic Reactive Gaseous Mercury in Ambient Air, Environ. Sci. Technol., 36, 3000-3009, 2002.

Laurier, F., Mason, R. P., Whalin, L., and Kato, S.: Reactive gaseous mercury formation in the North Pacific Ocean's marine boundary layer: A potential role of halogen chemistry, J. Geophys. Res., 108, 4529, doi:10.1029/2003JD003625, 2003.

Lee, D. S., Nemitz, E., Fowler, D., and Kingdon, R. D.: Modeling atmospheric mercury transport and deposition across Europe and the UK, Atmos. Environ., 35, 5455-5466, 2001.
Lin, C. J., Pan, L., Streets, D. G., Shetty, S. K., Jang, C., Feng, X., Chu, H.-W., and Ho, T. C.: Estimating mercury emissions outflow from East Asia using CMAQ-Hg, Atmos. Chem. Phys., 10, 1853-1864, doi:10.5194/acp-10-1853-2010, 2010.

Lindberg, S., Bullock, R., Ebinghaus, R., Engstrom, D., Feng, X., Fitzgerald, W., Pirrone, N., Prestbo, E., and Seigneur, Ch.: A synthesis of progress and uncertainties in attributing the sources of mercury in deposition, Ambio., 36, 19-32, 2007.

Lindberg, S. E. and Stratton, W. J.: Atmospheric mercury speciation: concentrations and behavior of reactive gaseous mercury in ambient air, Environ. Sci. Technol., 32, 49-57, 1998.

Lindberg, S. E., Brooks, S., Lin, C.-J., Scott, K. J., Landis, M. S. Stevens, R. K., Goodsite, M., and Richter, A.: Dynamic oxidation of gaseous mercury in the Arctic troposphere at polar sunrise, Environ. Sci. Technol., 36, 1245-1256, 2002.

Lu, J. Y., Schroeder, W. H., Barrie, L. A., Steffen, A., Welch, H. E., Martin, K., Lockhart, L., Hunt, R. V., Boila, G., and Richter, A.: Magnification of atmospheric mercury deposition to polar regions in springtime: the link to tropospheric ozone depletion chemistry, Geophys. Res. Lett., 28, 3219-3222, 2001.

Lynam, M. M. and Keeler, G. J.: Automated speciated mercury measurements in Michigan, Environ. Sci. Technol., 39, 9253 9262, 2005.

Malcolm, E. G. and Keeler, J. K.: Evidence for a sampling artifact for particulate-phase mercury in the marine boundary layer, Atmos. Environ., 41, 3352-2259, 2007.

Murphy, D. M., Hudson, P. K., Thomson, D. S., Sheridan, P. J., and Wilson, J. C.: Observations of mercury-containing aerosols, Environ. Sci. Technol., 40, 3163-3167, 2006.

Nguyen, H. T., Kim, K. H., Kim, M. Y., Hong, S., Youn, Y. H., Shon Z. H., and Lee, J. S.: Monitoring of atmospheric mercury at a Global Atmospheric Watch (GAW) site on An-Myun Island, Korea, Water Air Soil Pollut., 185, 149-164, 2007.

Obrist, D., Tas, E., Peleg, M., Matveev, V., Faïn, X., Asaf, D., and Luria, M.: Bromine-induced oxidation of mercury in the mid-latitude atmosphere, Nat. Geosci., 4, 22-26, doi:10.1038/NGEO10182011, 2010.

Pacyna, J., Wilson, W., and Steenhuisen, F.: Spatial distribution inventories of global anthropogenic emissions of mercury to the atmosphere, www.amap.no/Resources/HgEmissions/ HgInventoryMain.html, 2005.

Pacyna, E. G., Pacyna, J. M., Sundseth, K., Munthe, J., Kindbom, K., Wilson, S., Steenhuisen, F., and Maxon, P.: Global emission of mercury to the atmosphere from anthropogenic sources in 2005 and projections of 2020, Atmos. Environ., 44, 2484-2499, 2010.

Pirrone, N., Cinnirella, S., Feng, X., Finkelman, F. B., Friedli, H. R., Leaner, J., Mason, R., Mukherjee, A. B., Stracher, G. B., Streets, D. G., and Telmer, K.: Global mercury emissions to the atmosphere from anthropogenic and natural sources, Atmos. Chem. Phys., 10, 5951-5964, doi:10.5194/acp-10-5951-2010, 2010.

Poissant, L., Pilote, M., Beauvais, C., Constant, P., and Zhang, H. H.: A year of continuous measurements of three atmospheric mercury species (GEM,RGM and Hgp) in southern Québec, Canada, Atmos. Environ., 39, 1275-1287, 2005.

Polissar, A. V., Hopke, P. K., and Harris, J. M.: Source regions for atmospheric aerosol measured at Barrow, Alaska, Environ. Sci. Technol., 35, 4214-4226, 2001.

Schmolke, S. R., Schroeder, W. H., Kock, H. H., Schneeberger, D. 
Munthe, J., and Ebinghaus, R.: Simultaneous measurements of total gaseous mercury at four sites on a $800 \mathrm{~km}$ transect: Spatial distribution and short-time variability of total gaseous mercury over central Europe, Atmos. Environ., 33, 1725-1733, 1999.

Schroeder, W. H. and Munthe, J.: Atmospheric mercury - an overview, Atmos. Environ., 5, 809-822, 1998.

Seigneur, C., Lohman, K., Vijayaraghavan, K., and Shia, R. L.: Contributions of global and regional sources to mercury deposition in New York State, Environ. Pollut., 123, 365-373, 2003.

Seigneur, C., Vijayaraghavan, K., Lohman, K., Karamchandani, P., and Scott, C.: Global source attribution for mercury deposition in the united states, Environ. Sci. Technol., 38, 555-569, 2004.

Selin, N. E., Jacob, D. J., Park, R. J., Yantosca, R. M., Strode, S., Jaeglé, L., and Jaffe, D.: Chemical cycling and deposition of atmospheric mercury: Global constraints from observations, J. Geophys. Res., 112, D02308, doi:10.1029/2006JD007450, 2007.

Shetty, S. K., Lin, C. J., Streets, D. G., and Jang, C.: Model estimate of mercury emission from natural sources in East Asia, Atmos. Environ., 42, 8674-8685, 2008.

Sheu, G. R. and Mason, R. P.: An Examination of Methods for the Measurements of Reactive Gaseous Mercury in the Atmosphere, Environ. Sci. Technol., 35, 1209-1216, 2001.

Sheu, G. R., Lin, N. H., Wang, J. L., Lee, C. T., Ou Yang, C. F., and Wang, S. H.: Temporal distribution and potential sources of atmospheric mercury measured at a high-elevation background station in Taiwan, Atmos. Environ. 44, 2393-2400, 2010.

Sigler, J. M., Mao, H., and Talbot, R.: Gaseous elemental and reactive mercury in Southern New Hampshire, Atmos. Chem. Phys., 9, 1929-1942, doi:10.5194/acp-9-1929-2009, 2009.

Slemr, F., Brunke, E. G., Ebinghaus, R., and Kuss, J.: Worldwide trend of atmospheric mercury since 1995, Atmos. Chem. Phys., 11, 4779-4787, doi:10.5194/acp-11-4779-2011, 2011.

Swartzendruber, P. C., Jaffe, D. A., Prestbo, E. M., Weiss-Penzias, P., Selin, N. E., Park, R., Jacob, D. J., Strode, S., and Jaegle, L.: Observations of reactive gaseous mercury in the free troposphere at the Mount Bachelor Observatory, J. Geophys. Res., 111, D24302, doi:10.1029/2006jd007415, 2006.
Valente, R. J., Shea, C., Lynn Humes, K., and Tanner, R. L.: Atmospheric mercury in the Great Smoky Mountains compared to regional and global levels, Atmos. Environ., 41, 1861-1873, 2007.

Wan, Q., Feng, X. B., Julia, L., Zheng, W., Song, X. J., Han, S. J., and $\mathrm{Xu}, \mathrm{H}$.: Atmospheric mercury in Changbai Mountain area, northeastern China - Part 1: The seasonal distribution pattern of total gaseous mercury and its potential sources, Envrion. Res., 109, 201-206, 2009.

Wang, Y. Q., Zhang, X. Y., and Draxler, R. R.: TrajStat: GIS-based software that uses various trajectory statistical analysis methods to identify potential sources from long-term air pollution measurement data, Environ. Model. Soft., 24, 938-939, 2009.

Weiss-Penzias, P., Gustin, M. S., and Lyman, S. N.: Observations of speciated atmospheric mercury at three sites in Nevada: Evidence for a free tropospheric source of reactive gaseous mercury, J. Geophy. Res., 111, D24301, doi:10.1029/2006JD007415, 2009.

Wu, Y., Wang, S. X., Streets, D. G., Hao, F. M., Chan, M., and Jiang, J. K.: Trends in Anthropogenic Mercury Emissions in China from 1995 to 2003, Environ. Sci. Technol., 40, 5312-5318, 2006.

Yatavelli, R. L. N., Fahrni, J. K., Kim, M., Crist, K. C., Vickers, C. D., Winter, S. E., and Connell, D. P.: Mercury, $\mathrm{PM}_{2.5}$ and gaseous co-pollutants in the Ohio River Valley region: Preliminary results from the Athens supersite, Atmos. Environ., 40, 6650-6665, 2006.

Zhang, H.: Concentrations of speciated atmospheric mercury a high-altitude background station in the Shangri-La area of Tibetan Plateau, China, 10th International Conference on Mercury as a Global Pollutant, Abstract No. TG4B-P6, Halifax, Canada, 2011. 